Editorial

\title{
Boundary Spanning and Reconstitution in Migration
}

\author{
Anya Ahmed \\ School of Health and Society, University of Salford, Salford, M5 4WT, UK; E-Mail: a.ahmed@salford.ac.uk
}

Submitted: 5 March 2020 | Published: 25 March 2020

\begin{abstract}
The focus of this thematic issue is on migrants' experiences of belonging and non-belonging, and how communities are constructed in the destination country. It includes a group of international scholars across disciplines who are studying migration in a range of different contexts. Migration spans multiple disciplines and encompasses a variety of epistemological, ontological and methodological orientations. Despite such divergent approaches and positions however, there is consensus across the social sciences that understanding the dynamics of migration and mobilities is central to illuminating social relations within societies.
\end{abstract}

\section{Keywords}

belonging; community; identity; networks; non-belonging; place

Issue

This editorial is part of the issue "Boundary Spanning and Reconstitution: Migration, Community and Belonging" edited by Anya Ahmed (University of Salford, UK).

(C) 2020 by the author; licensee Cogitatio (Lisbon, Portugal). This article is licensed under a Creative Commons Attribution 4.0 International License (CC BY).

All forms of migration involve an attempt to enhance one's life in some way, whether this constitutes the choice to seek economic or employment opportunities, the drive to seek asylum or opting for a different lifestyle (Ahmed, 2015). Migration also necessitates motion across boundaries which can be geographical, political and cultural and, frequently, such boundaries are reconstructed in the migration destination (Ahmed, 2015). These boundaries can be symbolic, in flux, conditional and are reconstituted to signify belonging and nonbelonging (Ahmed, 2015; Anthias, 2008; Cohen, 1985; Yuval-Davis, Kannabiran, \& Vieten, 2006). Belonging can be understood as "the process of feeling or being a part of-rather than apart from" (Ahmed, 2015, p. 54). There are also temporal and spatial elements involved with belonging and again context is important. How and to what people construct belonging in a specific time and place illuminates how they see themselves in context, at both micro and macro levels (Ahmed, 2012, 2015; Marsh, Bradley, Love, Alexander, \& Norham, 2007). Community can be framed as multifaceted representations of belonging (Ahmed, 2011, 2015; Delanty, 2003). Another way of understanding belonging is to conceive of it as "a sense of intimacy with the world" (Boym, 2001, p. 251). The im- petus to address belonging (and non-belonging becomes more acute in the context of migration (Anthias, 2006), since we are not usually asked to define what we belong to unless we find ourselves in unusual circumstances (Amit, 2012).

Exploring how migrants search for, construct, imagine, symbolise, evoke and experience (or not) belonging and community in the host country provides the opportunity to consider what this represents from different perspectives in new contexts. Additionally, how people construct and experience belonging and community in migration sheds light on processes of social change and continuity from multiple vantage points (Ahmed, 2015). Boundaries characterise all forms of belonging and community whether related to place, networks or shared identity. Physical or geographical divides indicate who is of and from a place; for networks there are designated insiders and outliers; and with regard to identity, there are tangible and illusory characteristics which denote belonging and non-belonging (Ahmed, 2011, 2012, 2015). Yet although community is a well-known term, which is often "idealized" (Crow, 2002), it remains an ambiguous concept which is often called into question (Ahmed, 2015; Crow, 2002). 
Community denotes security, warmth and cosiness (Bauman, 2001), things in common (Cohen, 1982) and solidarity (Crow, 2002). It is also subjective and contextual encompassing belonging and non-belonging, sameness and otherness and inclusion and exclusion (Clark, 2007). In spite of this, community's elusiveness makes it useful to "think with" (Ahmed \& Fortier, 2003) in order to explore people's lived experiences of belonging and non-belonging through migration (Ahmed, 2011, 2012, 2015). In this way it can reveal the agency of individuals and groups in the context of social processes (Ahmed, 2015; Crow, 2002; Seeley, Sim, \& Loosley, 1956) and illuminate how this is influenced by wider structural factors (Castles, 2010; Giddens, 1991; Sherlock, 2002).

Individuals and groups can belong to different types of community concurrently and these can also be shifting (Temple et al., 2005) and it is impossible to completely separate them since place, networks and identity overlap (Ahmed, 2015). Belonging to place represents an emotional and embodied connection to the world (May, 2013) and community as place denotes living in or feeling belonging to a locale in a specific geographical area (Maclver \& Page, 1961; Murray, 2000). Network representations of community indicate being part of the social fabric (Anthias, 2008), relations of social bonding (Sherlock, 2002) or relational belongings (May, 2013) which are frequently symbolic for migrants (Ahmed, 2015; O'Reilly, 2000). Further, examining social relations and what people construct as shared (Amit \& Rapport, 2002) in conjunction with processes of exclusion and inclusion (King, Warnes, \& Williams, 1998; Rodriguez, Fernández-Mayoralas, \& Rojo, 1998) illuminates experiences of migration. is useful to understand migration experiences. There are multiple identities which people can claim or be ascribed, and again, identity is significant in discussions of community and migration. (Anthias, 2008). In this sense, community does not need to be tied to place or relate to networks but can instead relate to individual and group identification and ascription (Milner, 1968).

\section{Conflict of Interests}

The author declares no conflict of interests.

\section{References}

Ahmed, A. (2011). Belonging out of context: The intersection of place, networks and ethnic identity among retired British migrants living in the Costa Blanca. Journal of Identity and Migration Studies, 5(2), 2-19.

Ahmed, A. (2012). Networks among retired British women in the Costa Blanca: Insiders, outsiders, 'club capital' and 'limited liability.' Urbanities, 2(2), 95-112.

Ahmed, A. (2015). Retiring to Spain: British women's narratives of nostalgia, belonging and community. Bristol: Policy Press.
Ahmed, S., \& Fortier, A.-M. (2003). Re-imagining communities. International Journal of Cultural Studies, 6(3), 251-259.

Amit, V. (2012). Community and disjuncture: The creativity and uncertainty of everyday engagement. In V. Amit \& N. Rapport (Eds.), Community, cosmopolitanism and the problem of human commonality (pp. 3-73). London: Pluto Press.

Amit, V., \& Rapport, N. (2002). The trouble with community: Anthropological reflections on movement, identity and collective. London: Pluto Press.

Anthias, F. (2006). Belonging in a globalising and unequal world: Rethinking translocations. In N. Yuval-Davis, K. Kannabiran, \& U. Vieten (Eds.), The situated politics of belonging (17-31). London: Sage Publications.

Anthias, F. (2008). Thinking through the lens of translocational positionality: An intersectionality frame for understanding identity and belonging. Translocations: Migration and Social Change, 4(1), 5-20.

Bauman, Z. (2001). Community: Seeking safety in an insecure world. Cambridge: Polity Press.

Boym, S. (2001). The future of nostalgia. New York, NY: Basic Books.

Castles, S. (2010). Understanding global migration: A social transformation perspective. Journal of Ethnic and Migration Studies, 36(10), 1565-1586.

Clark, A. (2007). Understanding community (Real Life Methods Working Paper). Manchester and Leeds: National Centre for Research Methods, University of Manchester, and Leeds University.

Cohen, A. P. (1982). Belonging: Identity and social organisation in British rural cultures. Manchester: Manchester University Press.

Cohen, A. P. (1985). The symbolic construction of community. London: Routledge.

Crow, G. (2002). Community studies: Fifty years of theorization. Sociological Research Online, 7(3), 82-91. https://doi.org/10.5153/sro.742

Delanty, G. (2003). Community. London: Routledge.

Giddens, A. (1991). Modernity and self identity. Palo Alto, CA: Stanford University Press.

King, R., Warnes, A. M., \& Williams, A. M. (1998). International retirement migration in Europe. International Journal of Population Geography, 4(2), 91-111.

Marsh, P., Bradley, S., Love, C., Alexander, P., \& Norham, R. (2007). Belonging. Oxford: The Social Issues Research Centre.

Maclver, R. M., \& Page, C. H. (1961). Society: An introductory analysis. London: Macmillan.

May, V. (2013). Connecting self to society: Belonging in a changing world. Basingstoke: Palgrave Macmillan.

Milner, L. M. (1968). Factors influencing admission to a community mental health center. Community Mental Health, 4(1), 27-35.

Murray, M. (2000). Social capital formation and health communities: Insights from the Colorado Healthy Eating Communities Initiative. Community Development Journal, 35(2), 99-108. 
O'Reilly, K. (2000). The British on the Costa del Sol: Transnational identities and local communities. London and New York: Routledge.

Rodriguez, V., Fernández-Mayoralas, G., \& Rojo, F. (1998). European retirees on the Costa del Sol: A crossnational comparison. International Journal of Population Geography, 4, 183-200.

Seeley, J. R., Sim, R. A., \& Loosley, E. W. (1956). Crestwood Heights. New York, NY: Basic Books.

Sherlock, K. (2002). Community matters: Reflections from the field. Sociological Research Online, 7(2), 40-55. https://doi.org/10.5153/sro.720

Temple, B., Moran, R., Fayas, N., Haboninana, S., Mccabe, F., Mohamed, Z., . . . Rahman, N. (2005). Learning to live together. Developing communities with dispersed refugee people seeking asylum. York: Joseph Rowntree Foundation.

Yuval-Davis, N., Kannabiran, L., \& Vieten, U. (2006). The situated politics of belonging. London: Sage.

\section{About the Author}

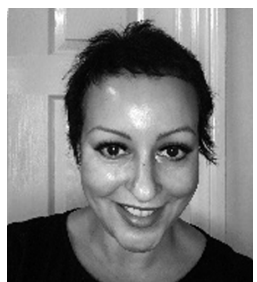

Anya Ahmed is Professor of Social Science in the School of Health and Society at the University of Salford. She has a background in social policy and sociology. She has led numerous funded projects focusing on the needs and experiences of less heard and marginalised communities. She has conducted research on migration/mobilities in the UK, Spain, Uganda and New Zealand and has published widely in these fields. 